\title{
Regional Innovation Policies for High-Technology Firms: The Importance of the Cluster Life Cycle
}

\author{
Paolo Calvosa \\ University of Naples Federico II, Naples, Italy
}

\begin{abstract}
The present work makes an in-depth analysis of an aspect not yet sufficiently examined by the studies into regional innovation systems, relating to why the policy makers must adopt regional innovation policies in accordance with the development cycle of the active clusters in the territory. The analysis carried out in the course of the work contributes towards understanding the validity of an evolutionary-type development model for which the regional innovation policies for the growth of high-tech firms should dynamically change in relation to the various cluster stages. The development model proposed provides a framework for the policy makers in order to state more efficiently through time the regional innovation strategies.
\end{abstract}

Keywords: regional innovation system, cluster life cycle, high-technology firms, regional innovation policy, evolutionary economic geography approach

\section{Introduction and Methodology}

Over the last few years, territory development strategies have been the object of numerous studies carried out in the sphere of various disciplines of the social and economic sciences. The territorial dimension has become a relevant object of investigation, as it has been shown that specific geographical areas are characterized by a set of "localized capabilities" (Maskell \& Malmberg, 1999) which are able to facilitate the innovation processes of business firms.

In the specific instance, the analysis perspective adopted by scholars of regional studies has utilized the system of innovation as a unit of investigation. In relation to a systemic interpretation of the innovation processes an institutionalized perspective has developed which has emphasized the role of the institutions in designing and exercising efficacious models of governance for the development of the firms' innovation at a regional level (Cooke, 2001).

Over time, concrete policies have been shaped by "best practice models" deriving from high-tech areas and well-performing regions, which are often in a similar way applied across many types of region. The analysis of some failed regional policies has shown that there is no single "best practices" innovation policy approach that is applicable everywhere (Tödling \& Trippl, 2005).

This is why in the last few years an evolutionary economic geography perspective has developed through which the policy makers have to possess a detailed knowledge of the regional innovation system specificities

Paolo Calvosa, University Researcher in Business Management, Department of Economics, Management, Institutions, University of Naples Federico II.

Correspondence concerning this article should be addressed to Paolo Calvosa, Department of Economics, Management, Institutions, University of Naples Federico II, Via Cinthia-Monte S. Angelo, Napoli, 80126, Italy. E-mail: calvosa@unina.it. 
and the factors underlying its dynamics to adopt a more differentiated innovation policy approach (Boschma \& Frenken, 2006). In keeping with this approach, the thesis has now been consolidated in literature whereby whenever the regional system is mostly characterized by the presence of high-tech clusters, they become central innovation strategies that differ from a regional system which is mainly characterized by the presence of midand low-tech clusters.

A relevant aspect which however does not yet prove to have been sufficiently well examined in the literature relates to how the regional innovation strategies must be modified in relation to the development cycle of the active clusters in the territory.

The aim of this work is to explain the validity elements of an evolutionary-type development model whereby the regional innovation policies for high-tech clusters should dynamically change in accordance with the various development stages of the cluster.

From the methodological viewpoint, the analysis develops through a reinterpretation, verification, and systematization process of the theoretical and empirical contributions produced on the theme, and makes provision for the adoption of a multidisciplinary approach characterized by utilizing the hypotheses, intuitions, and investigation instruments of the numerous research approaches which the object of research has, broadly speaking, been concerned with.

This work represents the first phase of a long-term research course which sets out to measure the effects of various policy measures in the different high-tech cluster life cycle phases.

The paper is divided into four sections. Section two deals with the literature review. In section three the connection is analysed between regional innovation policy and high-tech cluster life cycle, and a framework for the policy makers is proposed in order to state the regional innovation strategies more efficiently through time. The discussion is presented in section four, while the paper ends with conclusions, limits, and future research directions in section five.

\section{Literature Review}

\section{Regional Innovation Policies in an Evolutionary Economic Geography Perspective}

In the last few years while studying innovation processes of business firms associated with the territory, some scholars of regional studies have adopted a systemic analysis method which has emphasized the role of institutions in implementing governance models that are useful for supporting the development of these processes. Some researchers have, more especially, elaborated the concept of the national system of innovation, intending thereby to show how innovation systems are often associated with specific local contexts, in that they are strongly influenced by the institutional environment, especially at a national level (Lundvall, 1988, 1992; Freeman, 1991; Nelson, 1993; Edquist, 1997).

From the mid-1990s onwards several contributions closely associated with national system of innovation researches, also focusing on the use of a systematic analysis approach, has brought into discussion the appropriateness of the national analysis level in the study of innovation systems. Amongst others, reference is made to the contributions which have given place to the concept of "technological system" (Carlsson \& Jacobsson, 1997), of "sectoral systems of innovation and production" (Breschi \& Malerba, 1997) and further into the literature on the regional innovation systems (henceforth RIS) (Cooke, 1998; Asheim \& Cooke, 1999; Asheim \& Isaksen, 2002). The RIS concept has attracted the interest of researchers and policy makers, acting as a step of a passage towards a regional analysis scale, and as such, at any rate in theory, is characterized by 
innovation policies that are more "sensitive" to the context variables and competencies embedded in the territory.

The scholars who have analyzed the RIS concept have shown that to a great extent institutions bring about economic forms of behaviour by emphasizing the role that the regional innovation policies play in the development of the firms and the territory (Boschma \& Frenken, 2006).

With the passing of time this approach has led to the identification of best practices, often giving shape to an ideal and non-differentiated model of governance of local development which in many cases has been incapable of interpreting the differences among regions in terms of the patrimony of embedded knowledge, industrial specialization, competence deficits, and nature of local relationships (Fromhold-Eisebith \& Eisebith, 2005; Izzo, 2009). The analysis of some failed regional policies, especially in Europe, has shown that it is essential to distinguish between different forms of regional variety as they involve different economic effects (Tödling \& Trippl, 2005).

Some authors have therefore integrated the institutional approach with the evolutionary one. Viewed within an evolutionary perspective, knowledge creation processes are influenced either by the success or the failure of the previous attempts of creation, thus limiting the range of the possible directions towards which the business firm's innovation activity may be directed in the future (Nelson \& Winter, 1982). In describing the peculiar evolutionary nature of the firm's behavior, Dosi (1988) made use of the notion of "technological trajectory" in order to emphasize the importance of the analysis of the firm's long-term innovation processes, in that they are strongly path-dependent (Arthur, 1994), that is to say it connected to past experience and therefore to the dynamics of knowledge accumulation. This connects the technological development to the institutions and to the territorial conditions which at a local level affect this slow accumulation process (Martin \& Sunley, 2006; Laranja, Uyarra, \& Flanagan, 2008).

This is why in the last few years an evolutionary economic geography perspective has developed through which the policy makers' key role is expressed in fostering the learning processes, and above all, those of adaptation to history and knowledge embedded in the territory (Cooke, Uranga, \& Extebarria, 1998; Lambooy \& Boschma, 1999, 2001; Boschma \& Frenken, 2006; Boschma \& Martin, 2007).

As already observed (Lambooy \& Boschma, 1999), in an evolutionary perspective "history matters" in regional development. In terms of patrimony of the structures of institutions and ideas history often acts, at a regional level, as a filter for evaluating new opportunities for development.

The adoption of an evolutionary perspective thus indicates that:

Imitation of successful routines or institutions by other territories is inherently difficult [...]. Comparative analysis, including benchmarking of regions, has its limitations, as a set of successful micro-routines and macro-institutions cannot simply be carried over to different historical contexts. Comparisons are useful for analyzing which dimensions of an innovation system performed relatively poor and require adaptation, but they are less useful in providing solutions to fit the historical context of specific innovation systems. (Boschma \& Frenken, 2006, p. 289)

It has therefore been shown that "policy should promote dynamic matches between the specific evolving characteristics of technological trajectories and the characteristics of the region” (Laranja et al., 2008, p. 830).

\section{Regional Innovation Policies and Cluster Specialization}

Some RIS studies (Cooke, 2001; Asheim \& Coenen, 2005) in keeping with the evolutionary approach have pointed out the relevance of the link between regional innovation policies and sectoral specialization of 
the active clusters at a local level. They start out by considering that the local productive sub-system of production and exploitation of knowledge resources, which mainly comprises business firms, is often characterized by a tendency towards sectoral clustering.

The concept of cluster, elaborated by Porter $(1998,2000)$, is now very well known in the sphere of studies which have as their object the strategies for the internationalization of business firms and the industrial agglomeration processes ${ }^{1}$. According to Porter's definition, business firms and other local actors form part of the cluster if they perform their activities within the sphere of a "particular field" and is characterized by a technological production proximity which facilitates the development of relationships directed towards innovation. The interconnection aspect between local actors of a cluster is therefore cause and effect of the co-focusing of the activities on common sectoral themes. As observed (Asheim \& Coenen, 2005), a regional innovation system may therefore include several sectoral clusters and, in many cases, coincide with a specific sectoral situation. This is why in elaborating local development policies these authors show the need to consider the knowledge typology on the basis of the innovation processes more carefully, and hence the specificities of the clusters active in the sphere of these systems. In this regard, Asheim and Gertler (2005) argued that the innovation process of firms and industries is particularly dependent on their specific knowledge base, and make a distinction between two typologies of knowledge base namely "analytic" and "synthetic", as summarized in Table 1.

Table 1

Synthetic vs. Analytic Knowledge Base

\begin{tabular}{|c|c|}
\hline Synthetic & Analytic \\
\hline $\begin{array}{l}\text { Innovation by application or novel combination of existing } \\
\text { knowledge }\end{array}$ & ion by creation of new knov \\
\hline $\begin{array}{l}\text { Importance of applied, problem related knowledge (engineering) } \\
\text { often through inductive processes }\end{array}$ & $\begin{array}{l}\text { Importance of scientific knowledge often based on deductive } \\
\text { processes and formal models }\end{array}$ \\
\hline Interactive learning with clients and suppliers & $\begin{array}{l}\text { Research collaboration between firms (R\&D department) and } \\
\text { research organizations }\end{array}$ \\
\hline $\begin{array}{l}\text { Dominance of tacit knowledge due to more concrete know-how, } \\
\text { craft and practical skill }\end{array}$ & $\begin{array}{l}\text { Dominance of codified knowledge due to documentation in } \\
\text { patents and publications }\end{array}$ \\
\hline Mainly incremental innovation & More radical innovation \\
\hline
\end{tabular}

Note. Source: Asheim and Gertler (2005).

In keeping with Asheim and Coenen's (2005) observations and those of Asheim and Gertler (2005), and by utilizing the RIS classification elaborated by Asheim (1998), it is possible to identify three different RIS types, each of which is mainly linked to a different typology of knowledge at the bases of the innovation processes and therefore to specific clustered innovation processes.

The first RIS typology is defined as a "territorially embedded regional innovation system", where the business firms mainly exploit forms of synthetic knowledge and hence, as outlined in Table 1, base on their own innovative activities for most parts on localized learning processes through interaction, stimulated by geographical proximity, attributing a minor role to the links with the organizations specialized in research such as research centres and universities. Such a system mostly affects the business firms operating in the traditional sectors and therefore in general low- and medium-technology clusters (relevant examples of this RIS typology are the networks of small and medium firms operating in the industrial districts which regard traditional

\footnotetext{
${ }^{1}$ As observed by Martin and Sunley (2003), a proliferation has been witnessed over time of contributions based on such a concept. For an in-depth study of the "main disseminators of the cluster concept across time” (Caloffi et al., 2011).
} 
industries). The regional innovation policies in these systems should mainly aim at a support of a bottom-up type relationship directed towards facilitating the local industrial systemic development and towards providing services for transferring knowledge and for solving specific production problems.

The second RIS typology is defined as a "regionally networked innovation system". Also in these RIS the local development is more market-driven than science-driven. In this case, however, the innovation processes are more fuelled by new technologies and are characterized by a joint utilization of analytic and synthetic knowledge. The system tends to affect medium-technology clusters in terms of prevalence. In this case the regional innovation policies must focus on closer co-operation between public and private actors and attribute a more strategic role to the subjects specialized in research and development (R\&D), and to the bodies concerned with professional training and other typologies of local organizations involved in the business firms' innovation processes. This approach appears to have characterized the development of numerous regions in Germany, Austria, and Northern Europe.

The third RIS typology, defined as a "regionalized national innovation system", is finally characterized for innovation processes based on the analytic knowledge and interests of firms operating in the sphere of high-technology (or science-based ${ }^{2}$ ) industries in terms of prevalence. In these sectors, as outlined in Table 1, knowledge is produced mainly within the $\mathrm{R} \& \mathrm{D}$ department of the large business firms, but is also fuelled by university research findings or those of other research institutes. Thus compared with the RIS where the innovation processes are based on knowledge of a synthetic-type, such RIS is characterized by a greater frequency in the relationship between business firms and universities and for the prevalence of the codified nature of the utilized and produced knowledge resources. The significance of the codified knowledge derives from the fact that knowledge production processes, based on the application of scientific principles and methodologies and on processes formally organized having taken place in the R\&D departments, make use of the explicit research findings through scientific publications. Moreover, the innovation activity frequently takes place in cooperation with actors outside the region, and hence parts of the RIS industry and the institutional infrastructure are more functionally integrated into national or international innovation systems (Asheim \& Coenen, 2005). The prevalent use at a sectoral level of analytic knowledge does not imply, however, that tacit-type knowledge is irrelevant. In many cases, in fact, the two different knowledge typologies, tacit and codified, are used together in the innovation processes. Furthermore, new knowledge chiefly brings about new products or new production processes, such innovations often being of a radical type. Finally, this innovation process typology frequently gives place to the birth of new business firms, especially in the form of spin-off, which radically develop innovations and new products.

Coherently with the characteristics of the typical innovation processes of these RIS, the regional innovation strategies should concentrate mainly on policies of financing scientific research, on support actions for transferring know-how between business firms, universities, and scientific research centres, on initiatives aimed at facilitating the birth of university spin-off undertakings and the creation of business incubators and scientific and technological parks, on policies of address and facilitation for professional training centred on themes of sectoral specialization of the area, and on actions which consent linking the local cluster with global knowledge circuits.

\footnotetext{
2 According to the "Pavittian" sectoral taxonomy (Pavitt, 1984) based on nature and on the predominant sources of technological changes, the sectors of electronics and telecommunications form part of this category, as well as chemistry, pharmaceutics, biotechnology, and aerospace.
} 
In effect, the "regionalized national innovation system" is linked to the studies of authors who have elaborated the "triple helix" model (Etzkowitz \& Leydesdorff, 2000), "closely" associating the RIS concept with a type of innovation prevalently of a top-down type, founded on the reciprocal interaction between the academic and the entrepreneurial system, supported by the regional policy maker, who can foster the economic, occupational, and competitive growth of specific high-tech clusters (Cantone, Cirillo, \& Abbate, 2007).

\section{Regional Innovation Policies and Cluster Life-Cycle}

As already observed, in an evolutionary perspective the innovation policies at a regional level should be sensitive to local path dependencies (Lambooy \& Boschma, 2001) and "targeted at the need to restructure technological and sectoral composition” (Laranja et al., 2008, p. 830).

In keeping with this approach, the thesis has now been consolidated in literature whereby whenever the regional system is mostly characterized by the presence of high-tech clusters, they become central innovation strategies which differ from a regional system which is mainly characterized by the presence of medium and low technology clusters.

Some studies have over time analyzed through empirical research, the factors on the basis of the competitive advantage of firms operating in the sphere of high-tech clusters (Latouche, 1998; Longhi, 1999; Heath, 1999; Charles \& Benneworth, 2001; Maggioni, 2002; Bresnahan \& Gambardella, 2004; Wallsten, 2004; Wolfe \& Gertler, 2004; Braunerhjelm \& Feldman, 2006), facilitating the identification of the most efficient innovation policies to improve the development of the clusters.

More recently "there has been growing recognition that the existence of clusters can only be understood when studying their dynamics over time” (Boschma \& Fornahl, 2011, p. 1). Hence a series of research works have been carried out which have analyzed the concept of the cluster life cycle in order to describe the main features of cluster development over time, and to explore the driving forces behind their evolution.

The concept of cluster life cycle envisages that it follows different evolution phases in keeping with what happens to the product life cycle (Vernon, 1966) or to the industry life cycle (Keppler, 1997).

Industry life cycle studies have analyzed the industrial evolution purely in terms of the underlying industrial dynamics of entry and exit of firms competing in a particular industry. These studies have shown that the development of the clusters is linked to the industry life cycle in which it is specialized (Keppler, 1997; Brenner, 2001). However it has been shown that:

The whole notion of cluster lifecycles is based on the idea that, even if industrial and cluster evolution are correlated statistically, they cannot be equated [...]. For example, a cluster may decline while an industry is still growing, for example, if a lead firm relocates or a high-wage cluster faces competition from firms in low-wage countries. And, vice versa, a cluster may continue to grow despite the decline in an industry, for example, by specializing in high-end components or by diversifying into related industries. Therefore, cluster evolution is a separate object of study. (Frenken, Cefis, \& Stam, 2011, p. 14)

Over time various studies have more systematically analyzed the characteristics of the cluster life cycle and the differences with the industry life cycle (Maggioni, 2002; Iammarino \& McCann, 2005).

Some authors (Martin \& Sunley, 2003; Hassink, 2005, 2010; Malmberg \& Maskell, 2007; Crespo, Suire, \& Vicente, 2013) have dealt, in particular, with the theme of the evolution of the cluster in relationship with the aspect of the danger of the phenomena of technological lock-in. This phenomenon may affect the clusters in the phase of maturity in the sphere of which the production processes and innovation are connected with 
production and local practices surpassed by technological innovations developed in other contexts. These research works have shown that, generally speaking, in order to avoid the decline of the cluster, the institutions must motivate and facilitate the capacity of the business firms, and therefore that of the local system, to acquire new knowledge resources from outside which integrate with those possessed at a local level.

Other authors (Giuliani, 2010; Vicente, Balland, \& Brossard, 2011; Li, Bathelt, \& Wang, 2012; Ter Wal, 2013) have investigated how the network structures in clusters change over time, and how this affects the behavior and performance of cluster firms and the evolution of a cluster (Boschma \& Fornahl, 2011).

Inspired by recent developments in evolutionary economic geography, some of the more recent contributions have rendered the parameters more clearly according to which the cluster evolves and passes from one phase to the other.

In their seminal contribution, Menzel and Fornahl (2007, p. 1) have put forward a life cycle model "that explains the emergence, growth, decline and renewal of clusters and why the life cycle of clusters differs from that of industries". As emerges from Figure 1, this approach differs from the one followed by other authors in considering in the development of the cluster not only the classical quantitative dimensional aspects, such as the number of business firms and employees, but also those relevant ones relating to the level of heterogeneity of the knowledge on which the innovation processes are founded. On the basis of these variables four evolution phases of the cluster have been singled out, namely, emerging, growing, sustaining, and declining.

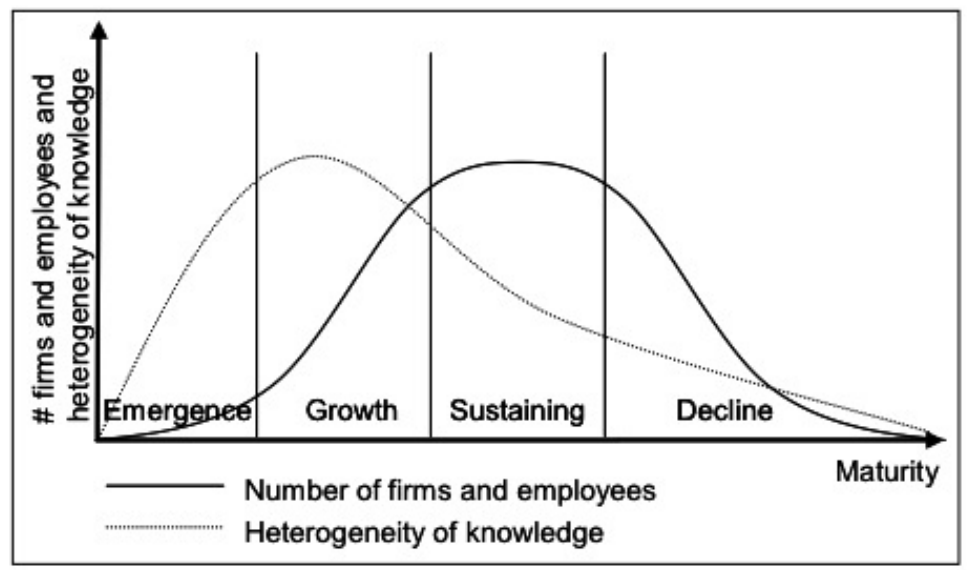

Figure 1. Quantitative and qualitative elements of the cluster life cycle. Source: Menzel and Fornahl (2007).

Referring to the subsequent paragraph for an in-depth study of the analysis of this model, it is important to point out that in the approach followed by these scholars:

The heterogeneity of the competencies available in the cluster is fundamental for its development. The cluster declines if its heterogeneity cannot be sustained. The cluster moves "back" in the cycle and enters a new growth stage, if the heterogeneity increases again. Therefore, the development of the cluster is not a deterministic movement from the left to the right, but a steady movement between the left and the right side of the figure. It is assumed that the movement of the most successful and established clusters takes place within the sustaining stage, in which they incrementally but steadily achieve to sustain their heterogeneity again and again. (Menzel \& Fornahl, 2007, p. 9)

Ter Wal and Boschma (2011) propose a theoretical framework similar to that of Menzel and Fornahl (2007) which however assembles literature on clusters, industrial dynamics, the evolutionary theory of the firm, and network theory. They describe how clusters co-evolve in the following phases, namely, introduction, 
growth, maturity, industry decline, or start a new cycle.

Setting out from the consideration that a cluster life cycle approach has several limitations, Martin and Sunley (2011) explored a different conception of cluster evolution drawing on the "adaptive cycle model" that has been developed in evolutionary ecology. Using this model, "cluster evolution is viewed as an adaptive process with different possible outcomes based on episodic interactions of nested systems” (Martin \& Sunley, 2011, p. 1299). They identify the following evolutionary trajectories of the cluster development: full adaptive cluster cycle, constant cluster mutation, cluster stabilization, cluster re-orientation, cluster failure, and cluster disappearance.

\section{Regional Innovation Policies and High-Technology Cluster Life Cycle: The Proposal for an Analysis Framework}

The analysis carried out has shown that in the last few years a series of research works have been performed which have analyzed the concept of the cluster life cycle. However, as observed by Boshma and Fornhal (2011, p. 3), “there are fundamental questions to be raised that are still relatively unexplored”. In particular, a relevant aspect which does not yet prove to have been sufficiently well examined in the literature relates to how the regional innovation policies are to be modified in relation to the development cycle of the active clusters in the territory. In this regard it has been observed (Brenner \& Schlump, 2011) that the connection between life-cycle theory and policy has been largely ignored.

The aim of this paragraph is to explain the reasons for which the regional innovation policies for a high-tech cluster should be adapted to the different stages of the cluster life cycle in order to improve its effects and to describe the actions of support priority to be brought about in each single development phase of the high-tech cluster, thereby providing the policy makers with a framework for stating more efficient the regional innovation strategies over time.

In this regard, it is useful to make certain methodological clarifications. A prime one concerns the fact that the considerations subsequently made are developed by reasoning in terms of prevalence where it is natural that the distinctions between production processes and innovation among specific sectors within the high-technology macro-sector may be relevant and require specific strategies for individual businesses. A second methodological clarification is associated with the observation that it is not always simple to be certain about the development phase in which a specific cluster is found (Menzel \& Fornahl, 2007). In fact, it may be characterized by the parties which find themselves in different phases of the evolution cycle. As subsequently examined further, the identification of the evolution phase of the cluster is carried out by evaluating the development level of the "focal part" of the cluster.

The analysis is carried out by using as reference the development model proposed by Menzel and Fornahl (2007) referred to in the previous paragraph. Keeping with the approach followed by these authors, and as transpires from Figure 1 reported earlier, it is possible to identify four evolution stages of cluster, namely, emerging, growing, sustaining, and declining.

As outlined in Table 2, the passage from one phase to the other is explained in both qualitative and quantitative terms, referring to two different aspects: on the one side direct development is analyzed in terms of the number of firms and employees (quantitative parameter), and in terms of knowledge typology on the basis of innovation processes of the cluster (qualitative parameter), while on the other side, the evolution of the cluster is associated with a systemic type dimension which, from the quantitative viewpoint, signals the 
perception of the cluster on the part of the actors and external investors and the capacity of the business firms of the cluster to bring about collective actions, and from the qualitative viewpoint, the support which the approximately developed systemic component may provide for the localized innovation processes.

Table 2

Cluster Life Cycle: Parameters and Evolutionary Key Factors

\begin{tabular}{|l|l|l|l|}
\hline & \multicolumn{4}{|l|}{ Parameters } \\
\hline Factors & Quantitative & \multicolumn{4}{|l|}{ Qualitative } \\
\hline Direct & $\begin{array}{l}\text { Size (number of firms and institutions number of } \\
\text { employees) } \\
\text { fiversity (knowledge, competencies and organisational } \\
\text { forms) }\end{array}$ \\
\hline Systemic & $\begin{array}{l}\text { Utilisation of the size (perception of the cluster, } \\
\text { capabilities for collective actions) } \\
\text { networks and value chains) }\end{array}$ & \\
\hline
\end{tabular}

Note. Source: Adaptation from Menzel and Fornahl (2007).

On the basis of the parameters described, Menzel and Fornahl (2007) identified the main characteristics distinguishing the various development phases of the cluster outlined in Table 3, and subsequently studied in depth.

Table 3

Cluster Life Cycle: The Characteristics of Emerging, Growing, Sustaining, and Declining Stages

\begin{tabular}{|c|c|c|c|c|}
\hline \multicolumn{5}{|c|}{ Parameters } \\
\hline Stage & Direct quantitative & Direct qualitative & Systemic quantitative & Systemic qualitative \\
\hline Emerging & Few firms and employees & Quite heterogeneous & $\begin{array}{l}\text { Hardly perceivable, few } \\
\text { possibilities for collective } \\
\text { actions }\end{array}$ & $\begin{array}{l}\text { Scarce possibilities for } \\
\text { interaction }\end{array}$ \\
\hline Growing & $\begin{array}{l}\text { Growing number of firms } \\
\text { and employment }\end{array}$ & Focussing & $\begin{array}{|lr|}\text { Growing perception, } \\
\text { possibilities for collective } \\
\text { action, institution building } \\
\end{array}$ & Open and flexible networks \\
\hline Sustaining & $\begin{array}{l}\text { Stagnating number of firms } \\
\text { and employment on a high } \\
\text { level }\end{array}$ & $\begin{array}{l}\text { Focussed competencies, } \\
\text { strong regional bias }\end{array}$ & Cluster shapes the region & $\begin{array}{l}\text { Open networks contribute to } \\
\text { utilise existing synergies } \\
\text { and external knowledge }\end{array}$ \\
\hline Declining & $\begin{array}{l}\text { Decline in number of firms } \\
\text { and employment }\end{array}$ & $\begin{array}{l}\text { Strong focus on a narrow } \\
\text { trajectory }\end{array}$ & $\begin{array}{l}\text { Negative sentiments with } \\
\text { respect to the cluster, partly } \\
\text { strong possibilities for } \\
\text { collective action }\end{array}$ & $\begin{array}{l}\text { Closed networks result in an } \\
\text { insufficient adaptability of } \\
\text { the cluster }\end{array}$ \\
\hline
\end{tabular}

Note. Source: Adaptation from Menzel and Fornahl (2007).

Consequently, one goes on to identify regional innovation policies for high-technology cluster priority in every individual phase of the development cycle, without excluding the fact that there are strategies which tend to be implemented during the cluster's entire life cycle.

\section{Regional Innovation Policies in the Emerging Stage of the High-Technology Cluster}

The emerging phase of the cluster is the most difficult one to be identified for the simple reason that in this phase the cluster is not such as yet, that is to say it is not the characteristic type of a clustered territorial structure. As shown in Table 3, in this phase the territory is still characterized by a much reduced number of firms operating in the specialization sector, and by a consequent reduced number of employees who tend to pass easily from one sector to the other. Consequently, the systemic dimension is extremely reduced, often being limited to the relationships which develop among few business firms and scientific institutions of reference. From the viewpoint of the knowledge available at a local level, the territory is characterized by sound heterogeneity, with the sectoral specialization of the production activities and the scientific research 
activities being further reduced.

In this phase "a specific institutional cluster environment is also shortcoming” (Menzel \& Fornahl, 2007, p. 17), and hence the role of policy makers proves once more to be rather limited.

However, as observed,

From theories of innovation and technological change we know that innovators will tend to emerge in location where technological opportunity are highest. When there are conditions of high opportunity, high appropriability, and high cumulativeness, innovators will tend to geographically concentrated, giving rise to emergent clusters. (Iammarino \& McCann, 2005, pp. 20-21)

Thus policy makers' initiatives appear useful which foster the presence of certain context conditions not yet closely linked to the specialization sector, such as the infrastructural endowment, the presence of skilled human capital (Boschma \& Van Der Knaap, 1999) as well as that of the solid basis of scientific knowledge (Braunerhjelm \& Feldman, 2006). In other words, these conditions assume the role of pre-conditions necessary for the high-technology cluster to emerge.

In this phase financing for the basic scientific research may allow providing the territory locally with an advanced set of analytical knowledge which may represent "the fuel" for "starting up" the development of the cluster.

Furthermore, the policy maker may adopt certain actions in support of the growth of some, albeit small, high-technology business firms which are characterized by a new vision of long-term development, as they may represent the nucleus around which the cluster may develop in the future, thus contributing towards creating a sort of "embryonic cluster".

Relevant among these initiatives are those aimed at giving support—and not only financial— to creating start-up and university-type spin-off firms in the high-tech sectors (Brenner, 2001). Likewise initiatives are useful which facilitate collaborative relationships among high-tech firms and between these and scientific research institutes, such as the creation of business incubators, even if this is made more difficult by the high level of knowledge heterogeneity which limits the capacity for dialogue among the actors.

\section{Regional Innovation Policies in the Growing Stage of the High-Technology Cluster}

If the cluster develops, then it enters the growth phase, in which it begins to be characterized by the typical clustered development elements of the territory and to have more defined confines. Generally speaking, the growth phase is marked by development rates of the elements of the cluster greater than the sector average.

As outlined in Table 3, in this phase the cluster is characterized by a higher number of firms in the specialization sectors and by an increased average dimension of the same, as well as by increased employment. From the knowledge diversity degree viewpoint, a reduced heterogeneity level is presented caused by a process of convergence towards sectoral themes, a process which tends towards defining the confines of the cluster more clearly. These changes have an influence on the systemic dimension. The increased cluster dimension, together with greater knowledge-focusing, fosters the innovation processes developed in the sphere of local networks among firms, suppliers, and scientific institutions. Moreover a specialized workforce market tends to be formed. All these transformations bring about an increase in the degree of cluster perception on the part of outside actors and investors, and supports the capacity of the firms of the local system to bring about the collective actions aimed at developing the cluster.

Together with the growth of the cluster, the role also develops that the regional policy makers can play to 
support its development.

Firstly, a sort of "meta vision" should be elaborated which allows clarifying a series of common innovation objectives or subjects operating in the area (Etzkowitz, 2002). This requires the policy makers to perform in-depth analyses of the potentialities of the productive and infrastructural subsystem in order to share with the main stakeholders of the territory (firms, industrial associations, public and private scientific research institutes, etc.) the strategic initiatives to be introduced, around which the efforts of the local development actors should be made to converge.

Central, in this regard, is the financing for the applied scientific research in the themes of sectoral specialization of the cluster, such as the initiatives supporting the transfer of know-how among business firms, and between business firms and scientific research institutes (Orsenigo \& Cancogni, 1999; Antonelli, 2001; Lundvall, 2005). Therefore actions in support of creating scientific parks and technopoles appear important (Cesaroni \& Gambardella, 1999; Castells \& Hall, 2000), in the sphere of which access is fostered towards and development of the firms and scientific institutions operating in the high-technology sectors, such as the creation of a regional technology transfer agency.

Moreover, all these initiatives, as shown by the "innovation economists" as well as by international business scholars, foster the development of localized knowledge spillovers which further support the firms' innovation processes (Jaffe, 1989; Cantwell, 2004), also activating a virtuous circle between expenditure in R\&D of a public and private type and attraction of business firms and private research centres.

In the growing cluster stage, moreover, with the increase in the perception level of the same also by external subjects, the policy makers may adopt facility policies to attract venture capital and business angels (Wallsten, 2004; Avnimelech \& Teubal, 2006). The exigency of financing funds for the technological start ups and research spin-off in fact becomes even more evident during this phase of growth.

Nevertheless, with affirmed sectoral specialization, the policies of addressing and facilitating professional training become fundamental. The policy makers should therefore commit themselves in the mediating activity, to the participation among firms, schools, universities, and private training centres, in training programmes in keeping with the new exigencies required by the local system of production.

\section{Regional Innovation Policies in the Sustaining Stage of the High-Technology Cluster}

The cluster enters a sustaining phase when the growth rates of the business firms and employees, albeit often still positive, tend to diminish if compared with those of the growth phases, and in most cases prove to be in keeping with the growth rates of the high-tech specialized sector of the cluster. As is shown in Table 3, affirmation of a cluster is presented in an equilibrium phase, characterized by an increase in focusing knowledge on the specific specialization themes from developed innovation processes closely associated with this knowledge and local networks.

The regional innovation policies should tend to upset this type of "cluster equilibrium" to prevent the same from evolving towards the decline phase. The danger of decline is primarily associated with the risk of a technological knowledge lock-in which can affect the areas in the sphere of which the innovation processes are connected to local production practices surpassed by technological innovations developed in other contexts (Bathelt, Malmberg, \& Maskell, 2004).

This risk is significant in the high-technology clusters within whose sphere that the innovation processes are often guided by radical innovations. The birth of new "disruptive technologies" (Dalum, Pedersen, \& 
Willumsen, 2002) may in fact bring about the decline in clusters which are unable to equate local knowledge with new technological trends associated with the industry life cycle.

This is why the regional institutions must stimulate and facilitate the capacity of the business firms and hence that of the local system to acquire knowledge resources from outside. The development policies must therefore evolve from a reactive approach of incremental improvement and distribution of welfare to a proactive one characterized by an opening up outwards in order to allow the influx of innovations, often of a radical type, produced in an international environment (Asheim, Boschma, \& Cooke, 2007).

In the innovation processes some studies have made an in-depth analysis of the role of the distance relationships and specific mechanisms which bring the local dimension of the business firms and the global one into contact. With the term "pipeline", understood as a channel of communication, Owen-Smith and Powell (2004) have defined the modality used to manage relationships set at a distance. They show that geographical distance does not represent the only factor assessed in the decisions leading towards creating relationships with other subjects aimed at innovation and which, therefore, the flows of knowledge which pass through a set of "network pipelines" are decisive in knowledge production processes. The firms therefore are not only included in local networks directed towards innovation, but also in cognitive networks not defined locally, but at a global level (Malmberg \& Maskell, 2007).

In the high-tech clusters, therefore, distance relationships play a very important role in that they are the instruments through which firms can access the codified knowledge resources on the basis of the renewal of the innovation processes. These complementary sources of learning are vital for innovation (Giuliani, 2010). For this reason in the sustaining stage regional policies for high-tech clusters, should favour:

- The development of distance business relationships, either enduring or based on the realization of specific projects aimed at innovation, with business firms, and more especially with research institutes of international importance;

- Participation in "temporary clusters", in sectoral scientific conventional forms, since they often permit access to research and innovation networks at a global level, exploiting the positive effects of temporary low cost geographical proximity (Maskell, Bathelt, \& Malmberg, 2005).

Still with the objective of opening up outwards, with the aim of permitting the influx of heterogeneous knowledge with respect to that rooted in the cluster, an important role is played by the installation of international firms in the territory which are leaders in the high-tech sectors. Some international business scholars (Bartlett \& Ghoshal, 1989; Doz, Santos, \& Williamson, 2000; Zanfei, 2000; Cantwell \& Piscitello, 2002) have analyzed the localization strategies of the large multinational business firms, and in this regard have shown how an organizational model is established with a network based on the multi-localized distribution of the innovation processes, which allow such multinational firms to combine the knowledge they possess with that rooted in "high-intensity knowledge areas" acquired through the setting up of branches. The presence of such business firms in the cluster thus allows the influx of knowledge possessed in the sphere of global networks onto the territory also through the spillover effect (Cantwell, 2004).

Therefore actions of territorial marketing in the strict sense of the word become determinant which:

- Point towards attracting towards the region international business firms which are technological leaders in the high-tech sectors of the cluster specialization;

- Foster the internationalization processes of business firms of the cluster in the "high-knowledge intensity areas". 


\section{Regional Innovation Policies in the Declining Stage of the High-Technology Cluster}

However, as outlined in Table 3, the cluster may enter a decline phase if a reduction is verified in the number of firms and, more especially of employees due to the failure of business firms and to rationalization processes. This process may be the consequence of the decline in the industry wherein the cluster is specialized, as well as of the poor capacity of the firms and of the policy makers to reduce the sound focusing of local knowledge on restricted technological trajectories, connected to the territory.

The local development strategies which the regional policy makers may adopt to help a high-tech cluster abandon the decline phase may be of two macro-typologies:

(1) The first macro-typology provides for the utilization of the strategies envisaged for the sustaining phase which have the objective of not making the cluster evolve towards a decline and that in the same way could be used to modify the negative development trend. Naturally the efficacy of these strategies diminishes if implemented in this phase, in that the decline has already begun and therefore it becomes more difficult to invert the process of an industrial crisis and, more especially, of accentuated focusing of knowledge. The inversion difficulties of the process are therefore reconnected to the phenomenon of the technological lock-in, further aggravated by the negative perception of the cluster on the part of the actors and outside investors;

(2) The second macro-typology of interventions provides for a sort of reconversion process of the cluster towards a new sectoral activity focus. In this case the strategies cannot be generalized but in an evolutionary perspective, they depend on the reconversion sector and must be directed towards overcoming obstacles against transformation. It is certain however, that reconversion requires strategies which direct towards the new focus of activities, facilitate investments in new fields of R\&D activities, and foster the entry and the birth of new actors within the cluster.

In Figure 2, on the basis of the observations made in the paragraph, the proposed framework is outlined that describes the actions of priority support to be brought about in each single development phase of the high-tech cluster. It represents a picture of reference to the policy makers in order to affirm the regional innovation strategies more efficiently over time.

\section{Discussion}

The analyses hitherto carried out keeping with the evolutionary perspective have granted understanding the reasons which in the development of the regional innovation policies require abandoning an "ideal approach" which does not give adequate consideration to the specificities of the territorial contexts in terms of patrimony of embedded knowledge, industrial specialization, competence shortcomings, and nature of local relationships.

Some interesting considerations emerge from the analysis:

Firstly, it is possible to observe that the relationships between regional innovation policies and phases of the high-tech cluster life cycle may be defined as "bi-univocal" in the sense that on the one side the passage from one phase of the development of the cluster to the other may also be a consequence of the policy makers' policies; on the other side, that such policies must vary in relationship to the different evolutionary stages of the cluster.

As emerges from Figure 2, these strategies are closely interrelated and are reciprocally fuelled over time. In Figure 2, for every phase of the life cycle, the "basic" innovation strategies are singled out in relationship to which the "derived" strategies are rejected. In fact, a sort of decisional order exists, according to which certain 
basic choices are to be elaborated as having priority in relationship to which, by adaptation, other strategies are to be subsequently implemented.

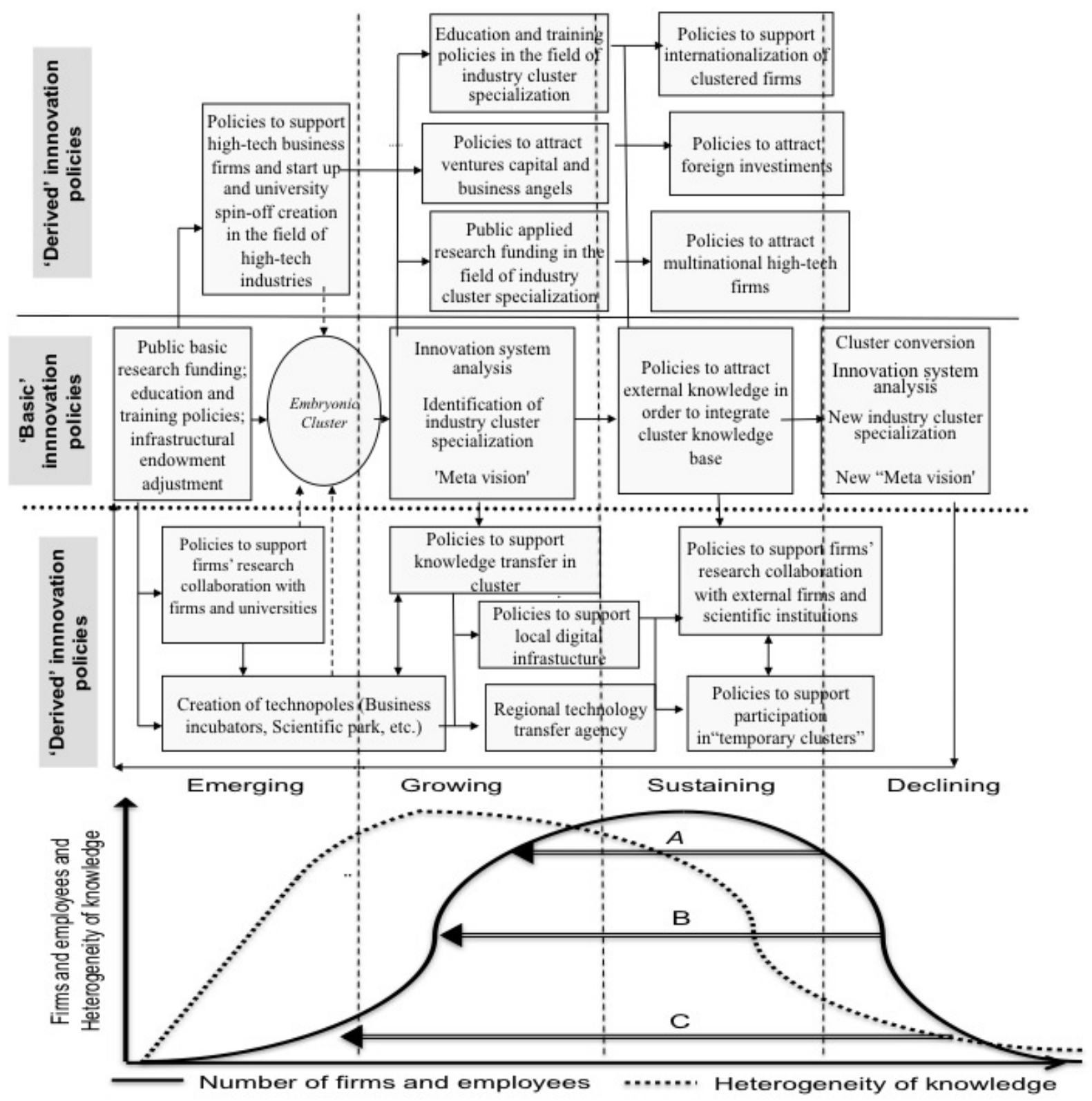

Figure 2. Regional innovation policies and high-technology cluster life cycle: A reference framework.

In the emerging stage the initiatives which foster the presence of the "pre-conditions" necessary for the cluster to emerge, and more especially the finance policies for the basic scientific research, are highly relevant.

In the growing stage, the development of a "meta-vision" of development, guided by the analysis of the characteristics of the embryonic cluster which has been affirmed at the end of the emerging phase may allow one to concentrate the efforts and investments of the production and infrastructural system of the area. The clarification of this meta vision may in fact drive the territorial stakeholders towards lining up their investments with the themes identified as focal points for the development of the cluster. 
In the sustaining stage, moreover, a key choice regards putting the initiatives into effect which allow upsetting an "equilibrium" situation which, albeit in the short term may lead to a further development of the cluster, and in the long term may bring about the decline of the same given the too close connection between local knowledge and practices and innovation processes. In this case the objective is to create a series of initiatives which lead to increasing the heterogeneity of the local knowledge resources, bringing about the influx of technological innovation from outside, different from that utilized on the territory. The end aim is that of draw the cluster towards a new growth phase (arrow A in Figure 2), in the viewpoint of a life cycle which is continually renewed over time.

Finally the decline phase is characterized either by the adoption of the strategies envisaged for the sustaining phase, also in this case with the objective of bringing back the life cycle of the cluster in the growth phase (arrow B in Figure 2), or through strategies which are directed towards a new activity focus, in the viewpoint of a sectoral reconversion process which should lead the cluster to a new emergent phase (arrow $\mathrm{C}$ in Figure 2).

The strategies indicated in Figure 2 as derived must therefore be lined up with the basic choices just described.

In conclusion, it is necessary to point out that in an evolutionary perspective for the regional innovation policies for the high-tech cluster to be more efficacious, it is useful for them to respect a general principle of coherence. Coherence between policies and typology of basic knowledge rooted in the territory; coherence between policies and historical evolution of production and the local infrastructural system, and thus with the phases of the life cycle of the cluster; coherence between basic and derived strategies; and coherence between "meta vision" of long-term development elaborated by the regional policy makers and interests of the various stakeholders of the territory.

\section{Conclusions, Limits, and Future Research Directions}

The analysis carried out in the course of the work permits evidencing relevant aspects regarding the connection between life cycle theory and regional innovation policies, which however does not yet prove to have been sufficiently well examined in the literature. As observed by Laranja et al. (2008, p. 831) "whilst economic theories provide principles for justification of public intervention and general directions for policies, they are not always prescriptive in terms of policy instrument choice”.

First, the research brings out the validity elements of an evolutionary-type development model whereby the regional innovation policies for the growth of the high technology firms should dynamically change in relationship to the various emerging, growing, sustaining, and declining stages of the cluster. Hence, this work contributes towards responding to a key question posed by the recent literature on cluster evolution, namely, "which kind of theoretical framework is required for analyzing cluster evolution” (Boschma \& Fornahl, 2011, p. 1).

In addition, the research contributes towards providing a framework to the policy makers in order to state more efficiently through time the regional innovation strategies. The development model proposed in fact describes the actions of support priority to be introduced into each single development phase of the high-tech cluster. It is necessary in this regard that the framework proposed does not intend to represent a development model to be adopted in a generalized manner, as much as a picture of reference to reflect on the need for a dynamic approach in implementing regional innovation policies. In other words, it is desirable to observe that 
the importance of the learning processes in fuelling the innovation dynamics, now consolidated in the literature, does not only regard the business firms or local systems, but also the policy makers who must continually monitor the territory in order to understand the information necessary for "modifying" and "innovating" their policies.

Moreover, it is necessary to point out that the development model proposed, albeit also based on reinterpreting the real experience of success (the findings of the studies which they have identified, through empirical research, the regional innovation policies useful for sustaining the growth of the high-tech clusters) and failure (more especially the empirical analysis results of the cases of decline of the clusters connected with the effects of the technological lock-in), requires a series of researches of an empirical nature in order to test the impact on the growth of the high technology clusters of the regional innovation policies identified as being the most coherent with specialization and with the development cycle of the cluster. The failure to test the model thus represents a limit to the research, a limit moreover deeply rooted in the cognitive objectives of the work. In fact it represents a first phase of a course of long-term research which has as its objective the validation of the theses proposed through the study of the empirical cases. In fact there are indeed few pieces of research which up to now have tackled this theme (for an exception see Brenner \& Schlump, 2011; Elola, Valdaliso, Aranguren, \& López, 2012). To do this, a second phase of the course of research will have as objective to "render the model operative", by overcoming certain methodological difficulties relating to the measuring modalities of the stage of the life cycle of the cluster, especially with regard to measuring the qualitative dimensions proposed in the work, and to the identification of the proxy variables measuring the regional innovation policies identified in the model.

Another methodological shortcoming refers to the fact that the analysis carried out in the work was conducted by postulating the existence of a unique typology of high-tech cluster in the RIS sphere. In this regard some scholars have shown that the presence in the same region of a cluster with bases of different but related knowledge, grants exploiting knowledge spillovers across complementary sectors connected to a related variety of knowledge. It has been shown in fact that:

Related variety may be a powerful concept which links knowledge spillovers to major innovations, economic renewal, new growth paths and regional growth. If a pervasive feature, it implies that the long-term growth and development of regions depends on their ability to diversify into new applications and new sectors while building on their current knowledge base and competencies. (Asheim \& Boshma, 2007, p. 7)

This opens up to a further possible development of research, in the direction of the study of how the regional innovation policies can exploit the positive effect on the economies of correlated diversity (Jacobs, 1969) deriving from the existence on the territory of clusters of different production specializations.

\section{References}

Antonelli, C. (2001). The microeconomics of technological systems. Oxford: Oxford University Press. Arthur, W. B. (1994). Increasing returns and path dependence in the economy. Ann Harbor: MichiganPress.

Asheim, B. T. (1998). Territoriality and economics: On the substantial contribution of economic geography. In O. Jonsson, \& L.

O. Olander (Eds.), Economic geography in transition (pp. 98-109). The Swedish Geographical Yearbook, Lund.

Asheim, B. T. (1999). Interactive learning and localised knowledge in globalising learning economies. GeoJournal, 49, 345-352.

Asheim, B. T., \& Coenen, L. (2005). Knowledge bases and regional innovation systems: Comparing Nordic clusters. Research Policy, 34(8), 1173-1190. 
Asheim, B. T., \& Cooke, P. (1999). Local learning and interactive innovation networks in a global economy. In E. J. Malecki, \& P. Oinas (Eds.), Making connections: Technological learning and regional economic change. Aldershot: Ashgate.

Asheim, B. T., \& Gertler, M. S. (2005). The geography of innovation: Regional innovation systems. In J. Fagerberg, D. Mowery, \& R. Nelson (Eds.), The Oxford handbook of innovation (pp. 291-317). Oxford: Oxford University Press.

Asheim, B. T., \& Isaksen, A. (2002). Regional innovation systems: The integration of local "sticky” and global "ubiquitous" knowledge. Journal of Technology Transfer, 27, 77-86.

Asheim, B. T., Boschma, R. A., \& Cooke, P. (2007). Constructing regional advantage: Platform policy based on related variety and differentiated knowledge bases. Regional Studies, 45(7), 893-904.

Audretsch, D. B., Bönte, W., \& Krabel, S. (2010). Why do scientists in public research institutions cooperate with private firms. DRUID (Danish Research Unit for Industrial Dynamics) Working Paper No. 10-27.

Avnimelech, G., \& Teubal, M. (2006). Creating venture capital industries that co-evolve with high tech: Insights from an extended industry life cycle perspective of the Israeli experience. Research Policy, 35(10), 1477-1498.

Bartlett, C. A., \& Ghoshal, S. (1989). Managing across borders: The transnational solution. Boston: Harvard Business School Press.

Bathelt, H., Malmberg, A., \& Maskell, P. (2004). Clusters and knowledge: Local buzz, global pipelines and the process of knowledge creation. Progress in Human Geography, 28(1), 31-56.

Boschma, R. A., \& Fornahl, D. (2011). Cluster evolution and a roadmap for future research. Regional Studies, 45(1), 1295-1298.

Boschma, R. A., \& Frenken, K. (2006). Why is economic geography not an evolutionary science? Towards an evolutionary economic geography. Journal of Economic Geography, 6(3), 273-302.

Boschma, R. A., \& Frenken, K. (2011). Technological relatedness and regional branching. In H. Bathelt, M. Feldman, \& D. Kogler (Eds.), Beyond territory: Dynamic geographies of knowledge creation, diffusion and innovation. London: Routledge.

Boschma, R. A., \& Martin, R. (2007). Constructing an evolutionary economic geography. Journal of Economic Geography, 7(5), 537-548.

Boschma, R. A., \& Van Der Knaap, G. A. (1999). New high-tech industries and windows of locational opportunity: The role of labour markets and knowledge institutions during the industrial era. Geografiska Annaler, 81(2), 73-89.

Braunerhjelm, P., \& Feldman, M. P. (2006). Cluster genesis: Technology-based industrial development. New York: Oxford University Press.

Brenner, T. (2001). Self-organisation, local symbiosis of firms and the life cycle of localised industrial clusters. Papers on Economics and Evolution \#0103, Max Planck Institute of Economics, Jena.

Brenner, T., \& Schlump, C. (2011). Policy measures and their effects in the different phases of the cluster life cycle. Regional Studies, 45(10), 1363-1386.

Breschi, S., \& Malerba, F. (1997). Sectoral innovation system: Technological regimes, schumpetarian dynamics, and spatial boundaries. In C. Edquist (Ed.), Systems of innovation: Technology, institutions and organizations (pp. 130-156). London: Pinter.

Bresnahan, T., \& Gambardella, A. (2004). Building high-tech clusters: Silicon Valley and beyond. Cambridge: Cambridge University Press.

Cantone, L., Cirillo, N., \& Abbate, A. (2007). Mobilizing heterogeneus resources and complementary competencies to improve for the competitive profile of regional innovation systems: The case of aerospace RIS in Campania. Sinergie, 26, $289-298$.

Cantwell, J. A. (2004). Introduction. In J. A. Cantwell (Ed.), Globalization and the location of firms (pp. XI-XXV). Cheltenham: Edward Elgar.

Cantwell, J. A., \& Piscitello, L. (2002). The location of technological activities of MNCs in European regions: The role of spillovers and local competencies. Journal of International Management, 8(1), 69-96.

Carlsson, B., \& Jacobsson, S. (1997). Diversity creation and technological systems: A technology policy perspective. In C. Edquist (Ed.), Systems of innovation: Technologies, institutions and organizations. London: Pinter Publishers.

Castells, M., \& Hall, P. (2000). Technopoles of the world: The making of 21st century industrial complexes. London: Routledge.

Cesaroni, F., \& Gambardella, A. (1999). Dai “contenitori” ai “contenuti”: i parchi scientifici e tecnologici in Italia. In C. Antonelli (Ed.), Conoscenza tecnologica: Nuovi paradigmi dell'innovazione e specificità italiana. Torino: Edizioni della Fondazione Agnelli.

Charles, D., \& Benneworth, P. (2001). Clustering and economic complexity: Regional ICT clusters in the United Kingdom. In OECD (Ed.), Innovative clusters: Drivers of national innovation systems (pp. 327-346). Paris: OECD Proceedings. 
Cooke, P. (1998). Introduction: Origins of the concept. In H. J. Braczyk et al. (Eds.), Regional innovation systems. London: UCL Press.

Cooke, P. (2001). Regional innovation systems, clusters, and the knowledge economy. Industrial and Corporate Change, 10(4), 945-974.

Cooke, P., Uranga, M. G., \& Extebarria, G. (1998). Regional innovation systems: An evolutionary perspective. Environment and Planning, A(30), 1563-1584.

Crespo, J., Suire, R., \& Vicente, J. (2013). Lock-in or lock-out? How structural properties of knowledge networks affect regional resilience. Retrieved from http://ssrn.com/abstract=2034901

Dalum, B., Pedersen, C. R., \& Villumsen, G. (2002). Technological life cycles: Regional clusters facing disruption. DRUID Working Papers No. 02-10, DRUID, Copenhagen Business School.

Dosi, G. (1988). The nature of the innovative process. In G. Dosi et al. (Eds.), Technical change and economic theory (pp. 221-238). London: Pinter Publishers.

Doz, Y. L., Santos, J., \& Williamson, P. (2000). The metanational corporation: Competing globally in the knowledge economy. Cambridge: Harvard Business School Press.

Edquist, C. (1997). Systems of innovation: Technologies, institutions and organizations. London: Pinter.

Elola, A., Valdaliso, J. M., Aranguren, M. J., \& López, S. (2012). Cluster life cycles, path dependency and regional economic development: Insights from a meta-study on Basque clusters. European Planning Studies, 20(2), 257-279.

Etzkowitz, H. (2002). MIT and the rise of entrepreneurial science. London: Routledge.

Etzkowitz, H., \& Leydesdorff, L. (2000). The dynamics of innovation: From national systems and “Mode 2” to a triple helix of university-industry-government relations. Research Policy, 29(2), 109-123.

Freeman, C. (1991). Networks of innovators: A synthesis of research issues. Research Policy, 20(5), 5-24.

Frenken, K., Cefis, E., \& Stam, E. (2011). Industrial dynamics and economic geography: A survey. Eindhoven Center for Innovation Studies (ECIS) Working Paper Series No. 11-07.

Fromhold-Eisebith, M., \& Eisebith, G. (2005). How to institutionalize innovative clusters? Comparing explicit top-down and implicit bottom-up approaches. Research Policy, 34(8), 1250-1268.

Giuliani, E. (2010). The role of technological gatekeepers in the growth of industrial clusters: Evidence from Chile. Papers in Evolutionary Economic Geography (PEEG) No. 1013.

Hassink, R. (2005). How to unlock regional economies from path dependency? From learning region to learning cluster. European Planning Studies, 13(4), 521-535.

Hassink, R. (2010). Locked in decline? On the role of regional lock-ins in old industrial areas. In R. Boschma, \& R. Martin (Eds.), Handbook of evolutionary economic geography. Cheltenham: Edward Elgar.

Heath, R. (1999). The Ottawa high-tech cluster: Policy or luck? In T. G. A. Roelandt, \& P. Den Hertog (Eds.), Boosting innovation: The cluster approach. OECD Proceedings. Paris: OECD.

Iammarino, S., \& McCann, P. (2005). The structure and evolution of industrial clusters: Transactions, technology and knowledge spillovers. Paper No. 138, SPRU Electronic Working Paper Series.

Izzo, F. (2009). Le politiche regionali per l’innovazione. Rassegna Economica, 1, 55-69.

Jacobs, J. (1969). The economy of cities. New York: Vintage Books.

Jaffe, A. (1989). Real effects of academic research. American Economic Review, 79, 957-970.

Klepper, S. (1997). Industry life cycles. Industrial and Corporate Change, 6(1), 145-181.

Lambooy, J. G., \& Boschma, R. A. (1999). Evolutionary economics and economic geography. Journal of Evolutionary Economics, 9, 411-429.

Lambooy, J. G., \& Boschma, R. A. (2001). Evolutionary economics and regional policy. Annals of Regional Science, 35(1), 113-133.

Laranja, M., Uyarra, E., \& Flanagan, K. (2008). Policies for science, technology and innovation: Translating rationales into regional policies in a multi-level setting. Research Policy, 37(5), 823-835.

Latouche, D. (1998). Do regions make a difference? The case of science and technology policies in Quebec. In H. J. Braczyk, P. Cooke, \& M. Heidenreich (Eds.), Regional innovation systems: The role of governances in a globalized world. London: UCL Press.

Li, P. F., Bathelt, H., \& Wang, J. (2012). Network dynamics and cluster evolution: Changing trajectories of the aluminium industry in Dali, China. Journal of Economic Geography, 12, 127-155. 
Longhi, C. (1999). Networks, collective learning and technology development in innovative high-technology regions: The case of Sophia-Antipolis. Regional Studies, 33(4), 333-342.

Lundvall, B. A. (1988). Innovation as an interactive process: From user-producer interaction to national system of innovation. In G. Dosi et al. (Eds.), Technical change and economic theory. London: Printer Publishers.

Lundvall, B. A. (1992). National systems of innovation: Towards a theory of innovation and interactive learning. London: Pinter. Lundvall, B. A. (2005). The university in the learning economy. DRUID Working Paper No. 02-06.

Maggioni, M. A. (2002). Clustering dynamics and the location of high-tech-firms. Heidelberg/New York: Physica-Verlag.

Malmberg, A., \& Maskell, P. (2007). Myopia, knowledge development and cluster evolution. Journal of Economic Geography, 7(5), 603-618.

Martin, R., \& Sunley, P. (2003). Deconstructing clusters: Chaotic concept or policy panacea. Journal of economic geography, 3(1), 5-35.

Martin, R., \& Sunley, P. (2006). Path dependence and regional economic evolution. Journal of Economic Geography, 6, 395-437.

Martin, R., \& Sunley, P. (2011). Conceptualizing cluster evolution: Beyond the life cycle model? Regional Studies, 45(10), 1299-1318.

Maskell, P., \& Malmberg, A. (1999). Localised learning and industrial competitiveness. Cambridge Journal of Economics, 23(2), 167-185.

Maskell, P., Bathelt, H., \& Malmberg, A. (2005). Building global knowledge pipelines: The role of temporary clusters. DRUID Working Paper No. 05-20.

Menzel, M., \& Fornahl, D. (2007). Cluster life cycles-Dimensions and rationales of cluster evolution. Proceedings from the DRUID Conference on “Geography, Innovation and Industrial Dynamics” (Denmark).

Nelson, R. R. (1993). National systems of innovations: A comparative study. Oxford: Oxford University Press.

Nelson, R. R., \& Winter, S. (1982). An evolutionary theory of economic change. Cambridge: The Belknap Press of Harvard University Press.

Orsenigo, L., \& Cancogni, E. (1999). Le relazioni università-industria in Italia. In C. Antonelli (Ed.), Conoscenza tecnologica. Nuovi paradigmi dell'innovazione e specificità italiana. Torino: Edizioni della Fondazione Agnelli.

Owen-Smith, J., \& Powell, W. W. (2004). Knowledge networks as channels and conduits: The effects of spillovers in the Boston biotechnology community. Organization Science, 15, 5-21.

Porter, M. E. (1998). Clusters and the new economics of competitiveness. Harvard Business Review, 76, 77-90.

Porter, M. E. (2000). Location, competition, and economic development: Local clusters in a global economy. Economic Development Quarterly, 14(1), 15-34.

Ter Wal, A. L. J. (2013). Cluster emergence and network evolution: A longitudinal analysis of the inventor network in Sophia-Antipolis. Regional Studies, 47(5), 651-668.

Ter Wal, A. L. J., \& Boschma, R. (2011). Co-evolution of firms, industries and networks in space. Regional Studies, 45(7), 919-933.

Tödling, F., \& Trippl, M. (2005). One size fits all? Towards a differentiated regional innovation policy approach. Research Policy, 34, 1203-1219.

Vernon, R. (1966). International investment and international trade in product cycle. Quarterly Journal of Economics, 80, 190-207.

Vicente, J., Balland, P. A., \& Brossard, O. (2011). Getting into networks and clusters: Evidence from the Midi-Pyrenean Global Navigation Satellite Systems (GNSS) collaboration network. Regional Studies, 45(7), 1059-1078.

Wallsten, S. (2004). The role of government in regional technology development: The effects of public venture capital and science parks. In T. Bresnahan, \& A. Gambardella (Eds.), Building high-tech clusters: Silicon valley and beyond. Cambridge: Cambridge University Press.

Wolfe, D. A., \& Gertler, M. S. (2004). Ontario’s regional innovation system: The evolution of knowledge-based institutional assets. In P. Cooke, M. Heidenreich, \& H. J. Braczyk (Eds.), Regional innovation systems (pp. 91-124). London: Taylor and Francis.

Zanfei, A. (2000). Transnational firms and changing organisation of innovative activities. Cambridge Journal of Economics, 24, 515-542. 